\title{
Anaesthesia and analgesia in the emergency department
}

\section{Introduction and goals}

More and more, anaesthetists are being asked by their Emergency Medicine colleagues to lend assistance in developing skills and expertise, quality assurance and policy related to the use of potent pharmacology in the Emergency Department (ED). This session is designed to educate the practising anaesthetist in the needs and limitations of the ED and to introduce them to the types of cases where their expertise may be of some use in the ED and to their Emergency colleagues. It will:

1. Define the classes of agents commonly used in the ED to sedate and control patient behaviour. Issues of policy, documentation and quality assurance are presented.

2. Discuss the approach to paediatric sedation and analgesia in the ED, with particular attention to the role of Ketamine.

3. Address the rapid tranquillization of the combative trauma patient, including the use of paralytic agents to control behaviour.

4. Address specific issues related to patient screening for ED sedation, discharge criteria from the ED, and ED sedation and the full stomach.

There are some very practical issues that relate to the administration of sedative agents in the ED that anaesthetists and emergency physicians must sort out if patients are to be well served. Pain management is poorly done in most EDs. ${ }^{1}$ Sedation and analgesia are essential components of emergency practice. ${ }^{2,3}$ Ordinarily, sedation to the point where the patient is unable to protect their airway and general anaesthesia are not. Anaesthetists are not present in the ED around the clock, are not available to the ED within time frames acceptable for patient care and unit efficiency and feel uncomfortable in the ED because it is unfamiliar. Together, anaesthetists and emergency physicians ought to be able to resolve issues related to sedation in the ED such as training, policy development and quality monitoring in the interest of patient care.

Michael F. Murphy MD FRCPC

\section{The controversy}

The use of "anaesthetic" medications in the ED by nonanaesthetists has stirred a controversy in both the anaesthesia and emergency medicine literature. On one hand, emergency physicians have discovered that muscle relaxants, potent opioids, and ultrashort acting anaesthetic induction agents have an important role to play in the management of patients seen in the ED..$^{4,5}$ On the other hand, anaesthetists have, what they feel are, well grounded fears regarding the safety of the patients when such medications are administered by non-anaesthetists.

When an anaesthetist sees, in the Emergency Medicine literature, opioids being used as sedatives, sedatives being used to control pain, a lack of any specialty wide monitoring standard and personnel that they perceive to have limited airway management skills, one can see where these fears originate. Emergency Medicine Specialists, on the other hand, believe that they $d o$ possess the skills and expertise necessary to use these potent medications safely and effectively in the Emergency Department (ED) setting.

Having a foot in both camps, the author is able to identify an element of territorialism on the parts of both groups of physicians! The bottom line is that patients are well served by the safe use of these medications in the ED, for the appropriate indications.

\section{Definitions}

The issue of "definitions" is not simple. Many different organizations and individuals have used similar terms to define differing techniques to suit their unique needs, with little uniformity emerging. ${ }^{6}$ This is particularly true when one comes to the topic of sedation. Terms such as light sedation, deep sedation, conscious sedation, and dissociative sedation are used and mean different things to different people. This is particularly true for conscious sedation.

Dr W Lawrence Roy in his editorial Anaesthetizing children in remote locations: necessary expeditions or anaesthetic misadventures in the Canadian Journal of 
Anaesthesia, August 1996 correctly identifies a particularly germane issue related to sedation, namely the term "conscious sedation." He quotes Coté: "This phrase is an oxymoron that should be removed from the medical literature ... let us be honest and call deep sedation exactly what it is and take proper care of these deeply sedated patients." ${ }^{\prime, 8}$

So let us deal with the more descriptive terms: light, deep, and dissociatipe sedation. Additional definitions (or "states") that require description include general anaesthesia and neurolepsis. It should be clear that the definitions embody elements of the endpoint desired as well as the class of agent selected. An understanding of the state required allows the appropriate selection of the class of agent and route of administration. Anaesthetists understand that sedation is a continuum of dose and effect. The challenge is to titrate the dose to a clearly defined "level of consciousness" endpoint in a safe manner.
General Anaesthesia consists of three components: hypnosis (sleep), analgesia, and muscle relaxation. A patient is adequately anaesthetised when awareness is obliterated, movement does not occur with incision and sympathoadrenal responses to surgical stimulation are blunted or eliminated. This is a home-made definition, but it will suffice for this discussion. The induction of general anaesthesia in the ED is rarely appropriate nor desired, and should be performed by appropriately trained personnel.

Major tranquillizers, including phenothiazines and butyrophenones (haloperidol, droperidol) are known as neuroleptics, and induce a state known as "neurolepsis." Four features characterize this state: quiescence, reduced motor activity, reduced anxiety and indifference to surroundings. If an opioid is added, the state is called "neuroleptanalgesia." The further addition of nitrous oxide may lead to "neuroleptanaesthesia." While patients may be neuroleptized in the

TABLE I Definitions, features and examples of medications used for sedation in the Emergency Department (ED).

\begin{tabular}{|c|c|c|}
\hline State & Features & Drugs \\
\hline Sedation & $\begin{array}{l}\text { Clouds Consciousness } \\
\text { Confuses Reality } \\
\text { Decreases Activity } \\
\text { Moderates Excitement } \\
\text { Calms the Patient } \\
\text { Antialgesic } \\
\text { Decreased Respiratory Drive } \\
\text { Facilitates or Induces Sleep }\end{array}$ & $\begin{array}{l}\text { Alcohols } \\
\text { Benzodiazepines } \\
\text { Barbiturates } \\
\text { Chloral Hydrate }\end{array}$ \\
\hline Analgesia & $\begin{array}{l}\text { Analgesia } \\
\text { Decreased Respiratory Drive } \\
\text { Sedation: Side-effect in } \\
\text { High doses }\end{array}$ & $\begin{array}{l}\text { Opioids: } \\
\text { Natural: } \\
\text { Morphine } \\
\text { Codeine } \\
\text { Semisynthetic: } \\
\text { Hydromorphone } \\
\text { Oxycodone } \\
\text { Synthetic: } \\
\text { Pentazocine } \\
\text { Meperidine } \\
\text { Fentanyl }\end{array}$ \\
\hline Dissociation & $\begin{array}{l}\text { Sedation } \\
\text { Analgesia } \\
\text { Amnesia } \\
\text { Dissociation } \\
\text { Catalepsy }\end{array}$ & $\begin{array}{l}\text { Phencyclidine } \\
\text { Ketamine }\end{array}$ \\
\hline Neurolepsis & $\begin{array}{l}\text { State of Quiescence } \\
\text { Reduced Motor Activity } \\
\text { Reduced Anxiety } \\
\text { Indifference to Surroundings } \\
\text { Mental Clarity }\end{array}$ & $\begin{array}{l}\text { Butyrophenones: } \\
\text { Haloperidol } \\
\text { Droperidol } \\
\text { Phenothiazines: } \\
\text { Chlorpromazine }\end{array}$ \\
\hline General anacsthesia & $\begin{array}{l}\text { Hypnosis } \\
\text { Analgesia } \\
\text { Muscle Relaxation }\end{array}$ & $\begin{array}{l}\text { Volatile } \\
\text { Intravenous } \\
\text { "Balanced" }\end{array}$ \\
\hline
\end{tabular}


ED, and "kiddie cocktails" (eg. DPT) essentially constitute neuroleptanalgesia, the author has never utilized the latter technique in emergency practice and discourages the use of such imprecise "cocktails."

Production of the "dissociative state" is limited to one medication, ketamine and thus sedation in the ED with ketamine is termed "dissociative sedation." Thalamoneocortical and limbic dissociation caused by this medication has four features: sedation, catalepsis, amnesia and analgesia. Its utility, safety and use in emergency paediatrics is supported by an enormous body of literature, and widespread acceptance of the technique in North America is occurring moderately rapidly. 9,10

The definitions of "conscious sedation" available in the literature, as discussed earlier, are variable and somewhat imprecise. In dentistry, conscious sedation is defined as an art consisting of three parts: profound local anaesthesia; judicious medication giving amnesia, not sedation; and verbal support. This definition is well suited to the practice and needs of dentistry, where it was intended, but is difficult to apply in emergency medicine. Bennet and Stewart in their chapter in "Pain Management in Emergency Medicine" give the following definition: "The patient is sedated, demonstrates no evidence of fear, anxiety or suffering, and remains responsive to commands." 11 This definition is a good one but requires a clear description of endpoints to be clinically useful. This author prefers a precise definition for deep sedation that clearly identifies an endpoint short of risking aspiration and apnoca: "Consciousmess is obtunded, speech is slurred, nystagmus exists, eyes are closed but open to voice, ventilation is adequate and airway reflexes are intact."

In 1985 the American Academy of Pediatrics published their "Guidelines for the Elective Use of Conscious Sedation, Deep Sedation, and General Anaesthesia in Pediatric Patients." 12 The updated version of June 1992 is titled "Guidelines for Monitoring and Management of Pediatric Patients During and After Sedation for Diagnostic and Therapeutic Procedures." 13 These excellent documents address the issues relevant to the administration of sedation in pediatrics. In these documents conscious sedation is equated with light sedation, and the term deep sedation is introduced. They define conscious sedation as "... a minimally depressed level of consciousness that retains the patient's ability to maintain a patent airway independently and continuously, and respond appropriately to physical stimulation and/or verbal command." Deep sedation on the other hand, ". . . is a controlled state of depressed consciousness or unconsciousness from which the patient is not easily aroused, which may be accompanied by a partial or complete loss of protective reflexes, including the ability to maintain a patent airway independently and respond purposefully to physical stimulation or verbal command." The documents then go on to discuss candidate selection, facilities and equipment, consent, personnel, monitoring and recovery care.

Appendix 5 of the 1992 document makes a recommendation regarding the issue of the "full stomach" for the patient to undergo sedation: "When proper fasting has not been assured, the increased risks of sedation must be carefully weighed against its benefits and the lightest effective should be used." Since all emergency patients are considered to have full stomachs, one would do well to pay special heed to this advice particularly if intravenous deep sedation or dissociative sedation is being considered.

This author feels that the goal of sedation in the ED is to match the needs of the patient and the procedure with the technique, while at all times maintaining rousability and protective airway reflexes. Granted, this is an exercise in pharmacologic and clinical precision, but if done correctly minimizes risks to the patient.

\section{Indications for sedation in the ED}

Light sedation is frequently required in paediatric emergency practice, more so than in adult emergency practice. The lightly sedated patient is drowsy or lightly asleep with tempered responses to minimally painful or distressing procedures such as local anaesthetic infiltration, iv starts, lumbar puncture, slit lamp examination, foreign body removal or vaginal examination. It is ordinarily administered $p o$ or $i m$, and not titrated to effect $i v$. In the 6-24 mo old, midazolam has been

TABLE II Potential indications for sedation in adults and children in the ED. Not all emergency physicians would agree with all of these indications.

\begin{tabular}{cc}
\hline Children & Adults \\
\hline Light Sedation: & Light Sedation: \\
Small lacerations & Unstable Cardioversions \\
IV Starts & Lumbar Puncture \\
Foreign Body Removals & Sexual Assault Examination \\
Lumbar Puncture & Chest Tube Insertion \\
Slit Lamp Examinations & \\
Sexual Assault Examination & \\
& \\
Deep and Dissociative Sedation: & Deep and Dissociative Sedation: \\
Fracture Reductions & Fracture Reductions \\
Reduction of Dislocations & Reduction of Dislocations \\
CT Scanning & I \& D Abscesses \\
Corneal Foreign Body Removals & Emergency D \& C \\
Big Suture Procedures & \\
\hline
\end{tabular}


recommended via the nasal route, although the author has abandoned this route of administration as it is irritating to the patient. ${ }^{14}$ Importantly, these patients are not deeply sedated and require little more in terms of monitoring than continuous observation.

Deep sedation is required for procedures inflicting moderate to severe pain such as the reduction of fractures and dislocations. Medications are administered iv to allow precise titration to effect and to avoid the loss of protective reflexes. A reasonable (and safe) definition of deep sedation for use in the $\mathrm{ED}$, as mentioned above, would be to select a point on the continuum that delivered the following: "Consciousness is obtunded, speech is slurred, nystagmus exists, eyes are closed but open to poice, ventilation is adequate and airway reflexes are intact."

Production of this state is a precise pharmacological exercise requiring considerable skill and attention to detail. Single $p o$, im and $p r$ doses of medications such chloral hydrate and pentobarbital have been used for years to produce deep sedation in children undergoing diagnostic and therapeutic procedures such as CT scanning and radiotherapy. While success rates hover around $\mathbf{8 0} \%$ for these techniques, and deaths are rare, it is the author's opinion that the use of single, large doses of medications to produce deep sedation is fraught with hazard and, in general, is to be discouraged. The exception to this rule is deep sedation with ketamine, also known as dissociative sedation.

\section{Medications and techniques}

Whether one is starting an intravenous infusion in a nine month old, performing a vaginal examination in a five year old, or reducing a Colles, fracture in a 44-yr-old some degree of sedation, analgesia and muscle relaxation is required to achieve success and be acceptable to the patient. The patient should be in a compromised state for as brief a period as possible. Thus, the appeal of the ultrashort acting agents such as midazolam, thiopentone, propofol, fentanyl and alfentanyl over the more traditional agents such as diazepam, meperidine, morphine, chlorpromazine, haloperidol and others. ${ }^{15,16}$

The underlying condition of the patient is an important determinant of the skill level requirement of the personnel, the sophistication of monitoring demanded and the venue where the procedure will be undertaken. Resuscitation equipment must be immediately available and will ordinarily define the area of the ED where sedation will take place.

Monitoring should be consistent with the depth of sedation and degree of risk involved. With the possible exception of light sedation, continuous observation and pulse oximetry are required for all patients having sedation administered. An experienced Emergency Nurse in attendance is sufficient for light sedation. However, for deep sedation, a physician skilled in acute resuscitation and airway management must be in continuous attendance. Additional monitoring modalities include pulse oximetry, blood pressure, cardiac monitoring and the immediate availability of a monitor/defibrillator. Like naloxone when opioids are being used, the ready availability of flumazenil is an added safety feature if benzodiazepines are to be used.

Chloral hydrate, pentobarbital and ketamine, are rarely used by Canadian anaesthetists for sedation outside of the operating room, unless perhaps they are involved in paediatric sedation. For this reason, it is reasonable to elaborate on these agents. In addition, the technique of "Rapid Tranquillization" bears description.

\section{Chloral hydrate and pentobarbital}

Chloral hydrate is a popular sedating agent in paediatric radiology, paediatric cardiology and paedodontics particularly for children less than 18 mo of age. It has a long record of safety and efficacy. Doses range between 50 and $100 \mathrm{mg} \cdot \mathrm{kg}^{-1}$. A dose of $70-80 \mathrm{mg} \cdot \mathrm{kg}^{-1}$ with a maximum dose of $2 \mathrm{~g}$ (the "high dose" regimen) produces acceptable levels of sedation for CT or MRI scanning $80-100 \%$ of the time. Sedation is produced within 30-60 min with recovery in 90-120 min. Complications are rare, the most common being nausea and vomiting, hyperactivity and upper airway obstruction secondary to over sedation. ${ }^{17-21}$ Experience in paediatric emergency medicine is limited and conclusions are difficult to draw. However, if time limits are of secondary importance, a role in semielective radiological procedures might be imagined.

Pentobarbital is popular in paediatric radiology for those patients older than $18 \mathrm{mo}$. The doses employed are in the $2-6 \mathrm{mg} \cdot \mathrm{kg}^{-1}$ range $p o$ or $i v$. Time courses with oral administration, and complication rates are similar to those with chloral hydrate. From an emergency medicine point of view it seems to suffer from the same limitations as chloral hydrate and is unlikely to provide any benefit over currently used regimens.

The substantial safety record for both of these agents speaks for itself. However, catastrophes have occurred and are related to improper monitoring and lack of airway management expertise. The technique is to be equated with deep sedation and appropriate monitoring and personnel standards adhered to.

\section{Ketamine}

Ketamine was synthesized from phencyclidine in 1963 and was introduced into clinical practice in 1970.22 Ketamine is classified as a general anaestheric agent by the World Health Organization and is widely used 
TABLE III Drugs and doses used in ED sedation

\begin{tabular}{|c|c|c|c|}
\hline Drug & Light Sedation & Deep Sedation & Induction \\
\hline Midazolam & $\begin{array}{l}\text { po } 0.5 \mathrm{mg} \cdot \mathrm{kg}^{-1} \\
\text { max } 10 \mathrm{mg} \\
\text { MR } .25 \mathrm{mg} \cdot \mathrm{kg}^{-1} \times 1 \\
\max \text { total } 15 \mathrm{mg} \\
\text { im } 0.1 \mathrm{mg} \cdot \mathrm{kg}^{-1}\end{array}$ & $\begin{array}{l}0.01-0.1 \mathrm{mg} \cdot \mathrm{kg}^{-1} \\
\text { titrated to effect } \\
\text { no maximum }\end{array}$ & $0.1-0.35 \mathrm{mg} \cdot \mathrm{kg}^{-1}$ \\
\hline Thiopentone & $\mathrm{N} / \mathrm{A}$ & $\begin{array}{l}0.2 \mathrm{mg} \cdot \mathrm{kg}^{-1} \text { titrated } \\
\text { to effect iv } \\
\text { no maximum }\end{array}$ & $3-5 \mathrm{mg} \cdot \mathrm{kg}^{-1}$ \\
\hline Methohexitone & $\mathrm{N} / \mathrm{A}$ & $\begin{array}{l}0.1 \mathrm{mg} \cdot \mathrm{kg}^{-1} \text { titrated } \\
\text { to effect ip } \\
\text { no maximum }\end{array}$ & $\mathrm{l}-2 \mathrm{mg} \cdot \mathrm{kg}^{-1}$ \\
\hline Propofol & $\mathrm{N} / \mathrm{A}$ & $\begin{array}{l}0.1 \mathrm{mg} \cdot \mathrm{kg}^{-1} \text { titrated } \\
\text { to effect ip } \\
\text { no maximum }\end{array}$ & $1-2 \mathrm{mg} \cdot \mathrm{kg}^{-1}$ \\
\hline Etomidate & $\mathbf{N} / \mathbf{A}$ & N/A & $0.3 \mathrm{mg} \cdot \mathrm{kg}^{-1}$ \\
\hline Chloral Hydrate & po $50 \mathrm{mg} \cdot \mathrm{kg}^{-1}$ & $\begin{array}{l}\text { po } 70-80 \mathrm{mg} \cdot \mathrm{kg}^{-1} \\
\text { maximum } 2 \mathrm{~g}\end{array}$ & $\mathrm{~N} / \mathrm{A}$ \\
\hline Pentobarb & $i m 2 \mathrm{mg} \cdot \mathrm{kg}^{-1}$ & $i m$ up to $6 \mathrm{mg} \cdot \mathrm{kg}^{-1}$ & N/A \\
\hline Ketamine & N/A & $\begin{array}{l}\text { iv } 0.1-0.5 \mathrm{mg} \cdot \mathrm{kg}^{-1} \\
\text { im } 1-2 \mathrm{mg} \cdot \mathrm{kg}^{-1} \\
\text { po } 4 \mathrm{mg} \cdot \mathrm{kg}^{-1}\end{array}$ & $1-1.5 \mathrm{mg} \cdot \mathrm{kg}^{-1}$ \\
\hline
\end{tabular}

throughout the world. It produces a "dissociative state" characterized by sedation, amnesia, analgesia, dissociation, catalepsy, vocalization and movement, and nystagmus. In a dose related fashion sedation, amnesia and analgesia precede dissociation and this may be useful clinically. Ketamine, as opposed to other "sedatives" has analgesic properties, which is also of clinical relevance. Ketamine has become very popular in paediatric emergency medicine practice for sedation. ${ }^{23,24,25}$

The drug produces considerable increases in heart rate and blood pressure that are probably related to the CNS stimulation produced. Ketamine is a dose-related respiratory depressant but the effect is not prominent in the relatively small doses used for dissociative sedation. There is a remarkable degree of bronchodilation that occurs with ketamine that has prompted its use in severe asthmatics to both forestall intubation and facilitate it in the acute care setting. ${ }^{26,27}$

There are several special issues that bear particular consideration with the use of ketamine in the ED. The first of these is the occurrence of "emergence" reactions. These patients are very restless, disoriented and confused and, at times, quite combative. The incidence is increased over the age of $15 \mathrm{yr}$, in women, in those who normally have vivid dreams, and in those with a history of personality problems. The incidence of reactions severe enough to necessitate pharmacological intervention (iv benzodiazepines) is probably $<1 \%$ of cases provided patients are selected appropriately, and are allowed to recover in a quiet area. Ketamine sedation in EDs that are unable to provide this recovery environment may be inappropriate. Most EDs limit ketamine sedation to those $<10 \mathrm{yr}$ of age and administer a small dose of a benzodiazepine prophylactically (eg., midazolam $0.1 \mathrm{mg} \cdot \mathrm{kg}^{-1}$ po) with ketamine.

Increases in ICP, BP and heart rate occur predictably with ketamine and should be accounted for in patient selection. Patients with URIs or pulmonary infections, both of which are common in the paediatric ED population, may be predisposed to laryngospasm if upper airway procedures are undertaken using ketamine for sedation. Salivation is prominent with ketamine and may also predispose to laryngospasm. The immediate availability of devices capable of producing substantial positive pressure is mandatory if ketamine is to be used for paediatric sedation in the ED.

The dose for dissociative sedation is $4 \mathrm{mg} \cdot \mathrm{kg}^{-1}$ po, $2 \mathrm{mg} \cdot \mathrm{kg}^{-1} \mathrm{im}$, or $0.2-0.5 \mathrm{mg} \cdot \mathrm{kg}^{-1}$ slowly iv and titrated to effect. These routes are especially useful in paediatric patients for the $45-60 \mathrm{~min}$ procedure, in place of "kiddie cocktails" and produce roughly the same recovery times of one to four hours. The intravenous preparation is administered orally, usually in a vehicle to hide the bitter taste, such as acetaminophen elixir or juice. Monitoring is no different from that utilized for deep sedation. Specific attention must be paid to discharge instructions due to the prolonged duration of motor instability after ketamine sedation and the risk of falls and injury. 


\section{Rapid tranquillization}

No discussion of emergency sedation would be complete without addressing the issue of rapid tranquillization of the combative patient in the ED..$^{28-30}$ The typical patient is head injured with varying degrees of intoxication, ventilatory reserve and haemodynamic stability. Although a variety of sedative medications may be used in this situation, none possesses the degree of cardiopulmonary stability of the butyrophenones, haloperidol $\left(\mathrm{Haldol}^{\mathrm{R}}\right)$ and droperidol (Inapsine $\left.{ }^{\mathrm{R}}\right)$.

Minimal respiratory depression and mild alpha blocking (droperidol>haloperidol) properties make them ideal agents for use in these situations. The usual dose for both agents begins at $0.1 \mathrm{mg} \cdot \mathrm{kg}^{-1} i \nu$ push and repeated every 5-10 min to a maximum of 0.5 $\mathrm{mg} \cdot \mathrm{kg}^{-1}$. While much higher doses (up to $550 \mathrm{mg}$ of haloperidol) have been used with remarkable cardiopulmonary stability, the author prefers to add small doses of a benzodiazepine to achieve the desired effect. The result is a much reduced dose of either drug used alone. If one is unable to gain vascular access due to patient combativeness, droperidol $i m$ (same dose as iv) has been shown to be as effective as quickly as iv haloperidol. ${ }^{31}$

\section{Potent opioids}

The development of the newer, synthetic opioids such as fentanyl, sufentanil and alfentanyl has been driven by a desire to obtund sympathoadrenal responses completely during cardiac anaesthesia. The appeal of fentanyl and alfentanyl to emergency physicians is related to their rapid onset, limited duration of action and paucity of cardiovascular side effects. ${ }^{32,33}$ While fentanyl has the same terminal elimination half life as meperidine and morphine (130-220 $\mathrm{min}$ ) its high fat solubility give it an evanescent clinical time course $(30 \mathrm{~min})$. The down side of such lipid solubility is the tendency for large doses of the drug to accumulate and produce prolonged clinical effects. Alfentanyl, on the other hand, has a terminal elimination half life of $80 \mathrm{~min}$ and, thus, a much reduced propensity to accumulate. Both are profound respiratory depressants but have few cardiovascular effects in haemodynamically stable patients. Muscular rigidity may occur and impair respiration if the drugs are given rapidly and in large doses (>5 $\mu \mathrm{g} \cdot \mathrm{kg}^{-1}$ fentanyl; $>20 \mu \mathrm{g} \cdot \mathrm{kg}^{-1}$ alfentanyl).

The usual doses used in emergency practice are 1-3 $\mu \mathrm{g} \cdot \mathrm{kg}^{-1}$ fentanyl or $8-10 \mu \mathrm{g} \cdot \mathrm{kg}^{-1}$ alfentanyl. As 20-30 min drugs, these agents are great for 20-30 min pain but are poor choices for the longer term management of severe pain for which meperidine or morphine are more appropriate choices.

\section{Policy development: deep sedation in the ED}

The development of a written policy for deep sedation in the ED is an appropriate framework for fostering a relationship between anaesthesia and emergency medicine. Key statements in the policy ought to address the following issues:

1. Who will/who won't? (eg., Emergency physicians, orthopaedic surgeons, etc)

2. Who's responsible for what? (eg., Drug administration, documentation, etc)

3. Area of the ED where it will be performed.

4. Precautions to be in place (eg., $0_{2}$, monitors)

5. Role of support personnel

6. Drug dispensing policy

7. Documentation

8. Consultation threshold and response by anaesthesia when called

In this process the participants must remain focussed on quality patient care and emergency department efficiency. It is important to recognise that specialists such as Orthopaedic Surgeons, Plastic Surgeons, Gastroenterologists and others may wish to undertake deep sedation in the ED and must be considered in the policy.

Ordinarily, the deep sedation procedure mandates the attendance of a skilled ED nurse in addition to the Emergency Physician to assist in patient monitoring and documentation during the procedure.

\section{Special issues}

In this author's opinion the American Academy of Pediatrics (AAP) has done an excellent job of addressing the issues of discharge, full stomach and monitoring in patients undergoing deep sedation and are summarized here.

TABLE IV Features of opioid analgesic agents used in the ED.

\begin{tabular}{lllll}
\hline Drug & $\begin{array}{l}\text { Relative } \\
\text { Potency }\end{array}$ & $\begin{array}{l}\text { Half Life } \\
\text { (min) }\end{array}$ & $\begin{array}{l}\text { Usual Dose } \\
\text { (mg or } \mu g \cdot k^{-1}\end{array}$ & $\begin{array}{l}\text { Cost } \\
\text { (CDN\$) }\end{array}$ \\
\hline Morphine & 1 & 130 & $0.15-0.2$ & 0.19 \\
Demerol & 0.20 & 210 & $1-2$ & 0.18 \\
Fentanyl & 120 & 220 & $1-2$ & 1.39 \\
Alfenta & 30 & 80 & $5-7$ & 1.50 \\
\hline
\end{tabular}




\section{Discharge criteria (reliable accompaniment)}

1. Cardiovascular function and airway patency are satisfactory and stable

2 . The patient is easily rousable and protective airway reflexes are intact

3. The patient can talk (age appropriate)

4. The patient can sit unaided (age appropriate)

5 . For a very young or handicapped patient, incapable of the usual expected responses, the presedation level of responsiveness or a level as close as possible to the normal level for that individual should be achieved

6 . The state of hydration is adequate (eg., able to tolerate oral fluids)

Patients discharged alone after deep/dissociative sedation must be fully able to care for and protect themselves.

\section{Full stomach}

If fasting is not assured, the risks of sedation must be weighed against the benefits, and the lightest effective sedation used. In practical terms, this may mean that a patient that would otherwise be deeply sedated in the ED would be referred for anaesthetic care, ordinarily in the OR.

\section{Monitoring}

Deep sedation and general anaesthesia are inseparable for the purposes of monitoring.

\section{Conclusion}

As in radiology, endoscopy and multiple other specialized areas of modern hospitals, patients are sedated in the ED on a daily basis. The situations are entirely analogous except for the fact that emergency departments are equipped to resuscitate patients and the physicians staffing these departments possess moderate to advanced airway management skills.

It is incumbent upon anaesthetists and emergency physicians to cooperate in ensuring an adequate standard of care is delivered to patients undergoing sedation and analgesia in the ED, and other areas of the hospital. As a "horizontal" specialty, emergency medicine relies on the expertise of many "vertical" specialties on a daily basis. Anaesthesia has the capacity to contribute educational, experiential and practical resources to the administration of sedation and analgesia in the ED.

\section{References}

1 Yaster M. Pain relief. Pediatrics 1995; 95: 427-8.

2 Woolard DJ, Terndrup TE. Sedative-analgesic agent administration in children: analysis of use and complications in the emergency department. J Emerg Med $1994 ; 12$ : 453-61.
3 Sacchetti A, Schafermeyer R, Gerardi $M$, et al. Pediatric analgesia and sedation. Ann Emerg Med 1994; 23 : 237-50.

4 Rotondo MF, McGonigal MD, Schwab CW, Kauder DR, Hanson CW. Urgent paralysis and intubation of trauma patients: is it safe? J Trauma 1993; 34: 242-6.

5 Kuchinski J, Tinkoff G, Rhodes $M$, Becher JW. Emergency intubation for paralysis of the uncooperative trauma patient. J Emerg Med 1991; 9: 9-12.

6 Coté CJ. Sedation protocols - why so many variations? (Editorial) Pediatrics 1994; 94: 281-3.

7 Roy WL. Anaesthetizing children in remote locations: necessary expeditions or anaesthetic misadventures? (Editorial) Can J Anaesth 1996; 43: 764-8.

8 Coté CJ. Monitoring guidelines: do they make a difference? Am J Roentgenol 1995; 165: 910-2.

9 Green SM, Nakamura R, Johnson NE. Ketamine sedation for pediatric procedures: part 1 , a prospective series. Ann Emerg Med 1990; 19: 1024-32.

10 Green $S M$, Jobnson NE. Ketamine sedation for pediatric procedures: part 2, review and implications. Ann Emerg Med 1990; 19: 1033-46.

11 Bennett RC, Stewart RD. Ketamine. In: Paris PM, Stewart RD (Eds.). Pain Management in Emergency Medicine. Norwalk, CT: Appleton \& Lange, 1988: 296-8.

12 Guidelines for the elective use of conscious sedation, deep sedation, and general anesthesia in pediatric patients. Committee on drugs, section on anaesthesiology. Pediatrics 1985; 76: 317-21.

13 Guidelines for monitoring and management of pediatric patients during and after sedation for diagnostic and therapeutic procedures. Committee on drugs. Pediatrics 1992; 89: 1110-5.

14 Connors $K$, Terndrup TE. Nasal versus oral midazolam for sedation of anxious children undergoing laceration repair. Ann Emerg Med 1994; 24: 1074-9.

15 Wright SW, Chudnofsky CR, Dronen SC, Wright MB, Borron SW. Midazolam use in the emergency department. Am J Emerg Med 1990; 8: 97-100.

16 Ramoska EA, Linkenbeimer R, Glasgow C. Midazolam use in the emergency department. J Emerg Med 1991; 9: 247-51.

17 Binder LS, Leake LA. Chloral hydrate for emergent pediatric procedural sedation: a new look at an old drug. Am J Emerg Med 1991; 9: 530-4.

18 Greenberg SB, Faerber EN, Aspinall CL. High dose chloral hydrate sedation for children undergoing CT. J Comput Assis Tomogr 1991; 15: 467-9.

19 Rumm PD, Takao RT, Fox DJ, Atkinson SW. Efficacy of sedation of children with chloral hydrate. South Med J 1990; 83: 1040-2. 
20 Hubbard AM, Markowitz RI, Kimmel B, Kroger $M$, Bartko $M B$. Sedation for pediatric patients undergoing CT and MRI. J Comput Assis Tomogr 1992; 16: 3-6.

21 Steinberg $A D$. Should chloral hydrate be banned? Pediatrics 1993; 92: 442-6.

22 White PF, Way WL, Trevor AJ. Ketamine - it's pharmacology and therapeutic uses. Anesthesiology 1982; 56: 119-36.

23 Gutstein $H B$, Johnson $K L$, Heard MB, Gregory G. Oral Ketamine preanesthetic medication in children. Anesthesiology 1992; 76: 28-33.

24 Tobias JD, Phipps S, Smith B, Mulhern RK. Oral Ketamine premedication to alleviate the distress of invasive procedures in pediatric oncology patients. Pediatrics 1992; 90: 537-41.

25 Qureshi FA, Mellis PT, McFadden MA. Efficacy of oral ketamine for providing sedation and analgesia to children requiring laceration repair. Ped Emerg Care 1995; 11: 93-107.

26 Strube PJ, Hallam PL. Ketamine by continuous infusion in status asthmaticus. Anaesthesia 1986; 41: 1017-9.

27 Howton JC, Rose J, Duffy S, Zoltanski T, Levitt MA. Randomized, double-blind, placebo-controlled trial of intravenous ketamine in acute asthma. Ann Emerg Med 1996; 27: 170-5.

28 Clinton JE, Sterner S, Stelmachers $Z$, Ruiz $E$. Haloperidol for sedation of disruptive emergency patients. Ann Emerg Med 1987; 16: 319-22.

29 Dubin WR, Feld JA. Rapid tranquillization of the violent patient. Am J Emerg Med 1989; 7: 313-20.

30 Walls $R M$. The combative trauma patient: a paradigm of trauma leadership (Editorial). J Emerg Med 1991; 9: 67-8.

31 Thomas HI, Schwartz E, Petrilli $R$. Droperidol versus haloperidol for chemical restraint of agitated and combative patients. Ann Emerg Med 1992; 21 : 407-13.

32 Chudnofsky CR, Wright SW, Dronen SC, Borron SW, Wright $M B$. The safety of fentanyl use in the emergency department. Ann Emerg Med 1989; 18: 635-9.

33 Barsan WG, Tomassoni AJ, Seger D, Danal DF, Ling LJ, Bartlett $R$. Safety assessment of high-dose narcotic analgesia for emergency department procedures. Ann Emerg Med 1993; 22: 1444-9. 


\section{L'anesthesie et l'analgesie a l'urgence}

Introduction et objectifs

De plus en plus, les urgentologues font appel aux anesthésistes pour l'acquisition de l'habilité et de la compétence, l'élaboration des programmes d'assurance-qualité et pour des renseignements sur l'usage de produits pharmaceutiques puissants en salle d'urgence. Cette présentation vise à initier l'anesthésiste aux besoins et aux limitations imposés par l'urgence et à certains types de situations pour lesquelles sa compétence peut être utile directement ou pour venir en aide à ses collègues qui pratiquent au service d'urgence (SDU). Les objectifs visés sont:

1. Préciser les classes d'agents utilisés généralement à l'urgence pour la sédation et le contrôle du comportement. Les problèmes de la documentation et de l'assurance qualité seront abordés.

2. Discuter de la sédation et de l'analgésie pédiatriques à l'urgence avec une attention particulière au rôle de la kétamine.

3. S'attaquer au problème de la pacification rapide du traumatisé combatif incluant l'utilisation d'agents paralysants pour le contrôle du comportement.

4. Discuter des problèmes spécifiques au choix de la sédation, aux critères de congé et au patient à l'estomac plein.

S'ils veulent bien servir le patient, les anesthésistes et les urgentologues doivent préciser certaines questions en rapport avec l'administration des sédatifs au SDU. La prise en charge de la douleur est inefficace dans la plupart des SDU. ${ }^{1}$ La sédation et l'analgésie sont des composantes essentielles de la médecine d'urgence. ${ }^{2,3}$ Ordinairement, la sédation au point où la protection des voies aériennes devient impossible n'a pas sa place au SDU, pas plus que l'anesthésie générale. Les anesthésistes ne sont pas toujours présents au SDU et ne sont pas disponibles non plus à certains moments où ils sont requis pour l'efficacité du service. Souvent, ils ne se sentent pas à l'aise dans ce milieu inusité. Ensemble, l'anesthésiste et l'urgentologue devraient être capables de résoudre dans le meilleur intérêt du patient les problèmes propres à la sédation à l'urgence, comme la formation, l'élaboration de lignes de conduite et le monitorage.

\section{La controverse}

L'utilisation de médications «anesthésiques» à l'urgence par des non-anesthésistes a soulevé une controverse tant
Michael F. Murphy MD FRCPC

dans la littérature anesthésique qu'urgentologique. D'une part, les urgentologues ont découvert qu'il existait des relaxants musculaires, des morphiniques puissants et des agents d'induction à action ultracourte susceptibles de jouer un rôle important dans la prise en charge des patients qu'ils reçoivent au SDU.,5 D'autre part, les anesthésistes entretiennent des craintes qu'ils croient bien fondées envers la sécurité des patients quand ces médicaments sont administrés par des médecins qui n'ont pas une formation d'anesthésiste.

Quand un anesthésiste constate dans une publication d'urgentologie que des morphiniques sont utilisés comme sédatifs, que des sédatifs sont utilisés comme analgésiques, qu'il existe une absence généralisée de standards pour la surveillance et que la compétence du personnel pour le contrôle des voies aériennes est selon eux limitée, on peut imaginer leurs craintes. Les spécialistes urgentologues d'un autre côté, croient qu'ils possèdent toutes les aptitudes et la compétence nécessaires pour utiliser ces médicaments puissants en toute sécurité et avec efficacité dans le cadre d'un service d'urgence.

Avec un pied de chaque côté de la frontière, l'auteur est bien placé pour reconnaitre que le territorialisme fait partie des attributs de chacun des deux groupes de médecins. Il n'en reste pas moins que, dans les SDU, les patients seraient mieux traités si les médecin utilisaient les médicaments à leur disposition de façon appropriée pour des indications appropriées.

\section{Définitions}

Le problème des définitions est complexe. Pour satisfaire leurs propres besoins, plusieurs organismes et individus se servent des mêmes termes pour décrire des techniques différentes ce qui élimine toute possibilité d'uniformité. ${ }^{6}$ Ceci est particulièrement vrai pour la sédation. Les termes tels que sédation profonde, sédation consciente, et sédation dissociative signifient ce qu'on veut bien leur faire dire. Cette remarque s'applique surtout à la sédation consciente.

Le Dr Lawrence Roy, dans un éditorial intitulé L'administration de l'anesthésie à des enfants dans des secteurs de l'bôpital éloigné, expédition nécessaire ou tribulations inutiles? publié en août 1996 dans le Journal canadien d'anesthésie identifie un problème relatif à la définition de la sédation, plus spécifiquement l'utilisation de l'expression «sédation consciente». Il y cite Côté : 
«Cette expression est absurde et devrait être retirée de la littérature médicale ... Soyons honnêtes et appelons la sédation profonde exactement ce qu'elle est et prenons soin comme il se doit des patients sous sédation profonde", ${ }^{7,8}$

Discutons plutôt des expressions plus descriptives : sédation légère, profonde et dissociative. Parmi les autres définitions (ou états) qui doivent être précisées, il faut mentionner l'anesthésie générale et la neurolepsie. La visée d'un effet permet de choisir la classe d'agent et la voie d'administration. Les anesthésistes comprennent que la sédation est en continuité avec la dose et l'effet. Le défi consiste à titrer la dose pour atteindre le niveau de conscience désiré sans déroger aux règles de sécurité.

L'anesthésie générale est constituée de trois éléments : l'hypnose (le sommeil), l'analgésie et la relaxation musculaire. Un patient est suffisamment anesthésié lorsque sa conscience est abolie, qu'il ne bouge pas au moment de l'incision et que ses réponses sympathico-adrénergiques à la stimulation chirurgicale sont émoussées sinon éliminées. Cette définition est personnelle mais n'est proposée que pour les fins de la discussion. L'induction de l'anesthésie générale à l'urgence est rarement indiquée, n'est pas désirable et ne devrait être effectuée que par une personne qui a reçu une formation spécifique.

Parce qu'ils induisent un état connu sous le vocable de neurolepsie, certains tranquillisants majeurs, dont les phénothiazines et les butyrophénones (halopéridol, dropéridol), sont identifiés comme des neuroleptiques. Quatre éléments caractérisent cet état : la quiétude, la réduction de l'activité motrice, la diminution de l'anxiété et l'indifférence face au milieu. Avec l'ajout d'un morphinique, cet état s'appelle la neuroleptanalgésie. L'ajout additionnel de protoxyde d'azote nous amène à la neuroleptanesthésie. Alors que des patients peuvent être «neuroleptisés» à l'urgence, et que les «cocktails» administrés quelquefois aux enfants constituent essentiellement de la neuroleptanalgésie, l'auteur ne l'a jamais utilisé ces cocktails neuroleptiques à l'urgence et décourage leur usage à l'urgence parce qu'ils sont trop lourds.

TABLEAU I Définitions, caractéristiques et exemples des médications utilisés pour la sédation à l'urgence

\begin{tabular}{|c|c|c|}
\hline Etat & caractéristiques & produits \\
\hline Sédation & $\begin{array}{l}\text { Obscurcissement de la conscience } \\
\text { Confusion de la réalité } \\
\text { Diminution de l'activité } \\
\text { Réduction de l'excitation } \\
\text { Quiétude du patient } \\
\text { Antialgie } \\
\text { Diminution du stimulus respiratoire } \\
\text { Induction ou facilitation du sommeil }\end{array}$ & $\begin{array}{l}\text { Alcools } \\
\text { Benzodiazépines } \\
\text { Barbituriques } \\
\text { Hydrate de chloral }\end{array}$ \\
\hline Analgésie & $\begin{array}{l}\text { Analgésie } \\
\text { Diminution du stimulus respiratoire } \\
\text { Sédation } \\
\text { Effets secondaires } \\
\text { Doses élevées }\end{array}$ & $\begin{array}{l}\text { Morphiniques: } \\
\text { Naturels: } \\
\text { Morphine } \\
\text { Codéine } \\
\text { Semi-synthétiques } \\
\text { Hydromorphone } \\
\text { Oxycodone } \\
\text { Synthétiques } \\
\text { Pentazocine } \\
\text { Mépéridine } \\
\text { Fentanyl }\end{array}$ \\
\hline Dissociation & $\begin{array}{l}\text { Sédation } \\
\text { Analgésie } \\
\text { Amnésie } \\
\text { Dissociation } \\
\text { Catalepsie }\end{array}$ & $\begin{array}{l}\text { Phencyclidine } \\
\text { Kétamine }\end{array}$ \\
\hline Neurolepsie & $\begin{array}{l}\text { Quiétude } \\
\text { Réduction de l'activité motrice } \\
\text { Réduction de l'anxiété } \\
\text { Indifférence à l'ambiance } \\
\text { Esprit clair }\end{array}$ & $\begin{array}{l}\text { Butyrophénones } \\
\text { Halopéridol } \\
\text { Dropéridol } \\
\text { Phénothiazines } \\
\text { Chlorpromazine }\end{array}$ \\
\hline Anesthésie & Hypnose & Volatils \\
\hline Générale & $\begin{array}{l}\text { Analgésie } \\
\text { Relaxation musculaire }\end{array}$ & $\begin{array}{l}\text { Intraveineux } \\
\text { Équilibree }\end{array}$ \\
\hline
\end{tabular}


Comme seule la kétamine peut induire l'état dissociatif; la sédation au SDU avec la kétamine s'appelle sédation dissociative. La dissociation thalamo-néocorticale et limbique propre à cette médication est caractérisée par la sédation, la catalepsie, l'amnésie et l'analgésie. Un nombre remarquable de publications a fait la preuve de son efficacité, sa sécurité en urgence pédiatrique et l'acceptation généralisée de cette technique en Amérique du Nord progresse assez rapidement. ${ }^{9,10}$

Les définitions de la sédation consciente trouvées dans la littérature, comme nous l'avons mentionné plus tôt, sont variables et plutôt imprécises. En dentisterie, la sédation consciente est définie comme un art à trois volets : anaesthésie locale approfondie, médication procurant l'amnésie sans sédation et appui verbal.

Cette définition est bien adaptée à la chirurgie dentaire et aux besoins des dentistes auxquels elle est destinée mais il est difficile de l'appliquer à la médecine d'urgence. Bennett et Stewart, dans leur chapitre sur la gestion de la douleur en médecine d'urgence, fournissent la définition suivante: «Le patient sous sédation, n'est ni craintif ni anxieux ni souffrant, et demeure capable de répondre aux commandements». ${ }^{11}$ Cette définition est valable mais pour être utilisable en clinique elle doit être précisée sous l'aspect des objectifs à atteindre. Pour la sédation profonde, cet auteur préfere une définition plus précise qui identifie clairement une visée qui inclut le risque d'aspiration et d'apnée: "La conscience est émoussée, la langue est pâteuse, le nystagmus est évident, les yeux sont fermés mais s'ouvrent sur demande, la ventilation est adéquate et les réflexes des voies aériennes sont intacts".

En 1985, l'American Academy of Pediatrics publiait des lignes de conduite sur l'usage de la sédation consciente et de l'anesthésie générale en pédiatric. ${ }^{12}$ Cette version mise à jour en 1990 est intitulée Guidelines for Monitoring and Management of Pediatric Patients During and After Sedation for Diagnostic and Therapeutic Procedures. ${ }^{13}$ Ces documents d'une grande valeur traitent des questions relatives à l'administration de la sédation en pédiatrie. On y définit la sédation consciente comme «un niveau de conscience très déprimé où le patient garde son habilité à maintenir de façon autonome et continue la perméabilité de ses voies aériennes tout en étant capable de répondre de façon appropriée à la stimulation physique et/ou à l'ordre verbal». D'autre part, la sédation profonde «est un état contrôlé de dépression de la conscience ou d'inconscience d'où le patient n'est pas facilement extrait et qui peut s'accompagner de la perte partielle ou complète des réflexes protecteurs y compris la capacité pour le patient de maintenir seul la perméabilité de ses voies aériennes et de répondre de facon appropriée à la stimulation physique ou aux ordres verbaux». Les directives discutent de la sélection des candidats, des facilités et de l'équipement, du consentement, du personnel, du monitorage et des soins de la période de récupération.

L'appendice 5 du document de 1992 fait la recommandation suivante sur le problème de l'estomac plein avant une sédation: "Quand on n'est pas sûr que la période de jeûne est suffisante, les risques accrus de la sédation doivent être pesés contre ses bienfaits et la sédation la plus légère possible doit être administrée». Comme à l'urgence tous les patients sont considérés comme des «estomacs pleins", il faut porter une attention toute spéciale à cette suggestion si on considère administrer une sédation intraveineuse profonde ou dissociative.

Cet auteur croit que le but de la sédation à l'urgence est de rencontrer les besoins du patient et ceux de l'intervention en maintenant un état constant de sédation propice au rétablissement rapide tout en protégeant les réflexes des voies aériennes. Il s'agit là d'un exercice de précision pharmacologique et clinique qui, réalisé correctement, éliminera une grande part du risque encouru.

\section{Indications de la sédation légère ou SDU}

Dans des circonstances identiques, la sédation légère réfêre le plus souvent à un patient assoupi ou quelque peu endormi qui maintient des réponses modérées au stimulus douloureux léger ou à une manoeuvre désagréable comme l'infiltration d'un anesthésique local, l'installation d'une perfusion, une ponction lombaire, un examen à la lampe à fente, une extraction d'un corps étranger ou un examen vaginal. La sédation est ordinairement administrée po ou $\mathrm{im}$. Chez l'enfant de 6 à 24 mois, l'administration nasale de midazolam a été recommandée bien que l'auteur ait abandonné cette méthode à cause de l'irritation qu'elle produit. ${ }^{14}$ Il faut mentionner particulièrement que ces patients ne sont pas sous sédation profonde et qu'en termes de monitorage, une attention continue est suffisante.

La sédation profonde est nécessaire pour des interventions modérément à très douloureuses comme les réductions de fracture ou de luxation. Les médicaments sont administrés iv pour un dosage précis et le maintien des réflexes protecteurs. Pour la description de la sédation profonde, on peut se référer au continuum suivant déjà mentionné : «La conscience est émoussée, la langue est pâteuse, le nystagmus est évident, les yeux sont fermés mais s'ouvrent sur demande, la ventilation est adéquate et les réflexes des voies aériennes sont intacts».

La production de cet état constitue une manipulation pharmacologique précise qui nécessite une habil- 
ité et une attention aux détails considérables. Les doses orales uniques, intramusculaires ou rectales de médicaments comme l'hydrate de chloral et le pentobarbital ont été utilisés chez les enfants pendant des années pour produire la sédation pendant des interventions diagnostiques et thérapeutiques comme la tomographie informatisée et la radiothérapie. Bien qu'avec ces techniques, le taux de succès oscille autour de $80 \%$ et que les mortalités soient rares, l'auteur pense que l'utilisation de fortes doses uniques de médicaments pour produire la sédation profonde est dangereuse et doit être en général découragée. La sédation profonde à la kétamine aussi connue sous le terme de «dissociative» constitue l'exception à la règle.

\section{Médications et techniques}

Que ce soit pour débuter une perfusion intraveineuse chez un bébé de neuf mois, pour effectuer un examen vaginal chez une fillette de cinq ans ou réduire une fracture de Colles chez un homme de 45 ans, l'exposition au danger doit être aussi brève que possible. Il est donc plus logique de faire appel aux agents dont l'action est ultracourte comme le midazolam, le thiopentone, le propofol, le fentanyl et l'alfentanil plutôt qu'aux agents traditionnels comme le diazépam, la mépéridine, la morphine, la chlorpromazine, l'halopéridol et quelques autres. ${ }^{15.16}$

Le niveau d'habileté du personnel, le raffinement du monitorage et l'endroit de l'intervention doivent être en corrélation avec la condition du patient. L'équipement nécessaire à la réanimation doit être disponible immédiatement et détermine ordinairement le secteur du SDU où se déroulera l'intervention

Le monitorage doit être adapté à la profondeur de la sédation désirée et au degré de risque encouru. À l'exception de la sédation légère, l'observation continuelle et l'oxymétrie de pouls sont requis chez tous les patient qui reçoivent la sédation. Pour la sédation légère, la surveillance par une infirmière expérimentée en soins d'urgence suffit. Cependant, pour la sédation profonde, un médecin habitué à la réanimation et à la gestion des voies aériennes doit être sur place continuellement. L'oxymétrie de pouls, la pression artérielle, l'ECG complètent le monitorage. Un moniteur/défibrillateur doit être accessible immédiatement. Comme le naxolone pour les morphiniques, la disponibilité du flumazénil constitue une mesure de sécurité additionnelle si des benzodiazépines sont utilisés.

Pour la sédation en dehors de la salle d'opération, l'hydrate de chloral, le pentobarbital et la kétamine sont rarement utilisés par les anesthésistes au Canada à moins qu'ils n'aient déjà pratiqué la sédation en pédiatrie. C'est la raison pour laquelle il est logique d'éla- borer sur ces agents. La technique de pacification rapide mérite aussi une description.

\section{L'bydrate de chloral et le pentobarbital}

L'hydrate de chloral est un sédatif populaire en radiologie, cardiologie et dentisterie pédiatriques particulièrement chez les enfants de moins de 18 mois. La posologie varie entre 50 et $100 \mathrm{mg} \cdot \mathrm{kg}^{-1}$. Une dose de 70 à $80 \mathrm{mg} \cdot \mathrm{kg}^{-1}$ avec un maximum de $2 \mathrm{~g}$ (le régime à haute dose) produit des niveaux acceptables de sédation pour la tomographie axiale et l'IRM dans 80 à $100 \%$ du temps. La sédation survient en 30 à 60 minutes et le réveil en 90 à 120 minutes. Les complications dont les plus fréquentes sont la nausée et les vomissements, l'hyperactivité et l'obstruction des voies aériennes supérieures secondaires à une sédation exagérée, sont rares. ${ }^{17,21}$ L'expérience de son utilisation en médecine d'urgence pédiatrique est limitée et il est difficile de tirer des conclusions. Cependant, si les limites de temps sont d'importance secondaire, l'hydrate de chloral pourrait être utile pour les interventions radiologiques semi-urgentes.

Le pentobarbital est populaire en radiologie pédiatrique pour les patients de plus de 18 mois. On administre des doses po ou iv de 2 à $6 \mathrm{mg} \cdot \mathrm{kg}^{-1}$. Avec l'administration po, le déroulement chronologique et le taux de complication sont les mêmes que ceux de l'hydrate de chloral. Du point de vue de la médecine d'urgence, il semble que ce médicament a les mêmes limitations que l'hydrate de chloral et il est peu probable qu'il puisse procurer des bénéfices supérieurs à ceux des régimes utilisés présentement.

Même si ces deux agents possèdent une marge de sécurité considérable, ils se sont trouvés au coeur de catastrophes impliquant l'insuffisance du monitorage

TABLEAU II Indications de la sédation chez les enfants et le adultes à l'urgence. Les urgentologues ne sont pas tous d'accord elles

\begin{tabular}{cc}
\hline Enfants & adultes \\
\hline Sédation légère: & $\begin{array}{c}\text { Sédation légère: } \\
\text { Cetite lacération }\end{array}$ \\
Mise en marche de perfusions & $\begin{array}{c}\text { Ponction lombaire } \\
\text { Extraction de corps étrangers }\end{array}$ \\
Ponction lombaire & Examen pour assaut sexuel \\
Examen à la lampe à fente & Insertion de drain thoracique \\
Examen pour assaut sexuel & \\
& \\
Sédation profonde et disociative: & Sédation profonde et diosociative: \\
Réduction de fracture & Réduction de fracture \\
Réduction de luxation & Réduction de luxation \\
Tomographie axiale & Ouverture et drainage d'abcès \\
Extraction de corps étranger cornéen & Dilatation et curetage urgent \\
Suture de plaies étendues & \\
\hline
\end{tabular}


et du contrôle gestion des voies aériennes. Cette technique est sur le même pied que la sédation profonde et les mêmes standards pour le monitorage et la compétence du personnel s'appliquent.

\section{La kétamine}

La kétamine a été synthétisée à partir de la phencyclidine en 1963 et introduite en clinique en $1970 .^{22} \mathrm{La}$ kétamine est classifiée comme anesthésique général par l'Organisation Mondiale de la Santé et on l'utilise à peu près partout dans le monde. Elle produit un état dissociatif caractérisé par la sédation, l'amnésie, l'analgésie, la dissociation, la catalepsie, la vocalisation et les mouvement involontaires, et le nystagmus. L'amnésie et l'analgésie sont proportionnelles à la dose et précèdent la dissociation ; cette caractéristique a son importance en clinique. La kétamine, contrairement aux autres sédatifs, possède des propriétés analgésiques. La kétamine est devenue un sédatif très populaire en médecine d'urgence pédiatrique. ${ }^{23,24,25}$

Cet agent provoque une augmentation marquée de la fréquence cardiaque et de la pression artérielle vraisemblablement en rapport avec la stimulation du SNC. La kétamine produit une dépression respiratoire proportionnellement à la dose, mais cet effet est peu important avec les doses relativement faibles utilisées pour la sédation dissociative. La kétamine procure un degré remarquable de bronchodilatation qui fait préconiser son utilisation chez les asthmatiques graves parce qu'elle permet d'éviter l'intubation et la facilite si elle devient essentielle. ${ }^{6,27}$

En ce qui concerne l'usage de la kétamine au SDU, plusieurs questions méritent une attention particulière. La première est l'apparition de réactions à la phase du réveil. Ces patients sont très agités, désorientés et confus, et quelquefois très combatifs. L'incidence de ces réactions augmente après l'âge de 15 ans, chez les femmes, chez ceux qui font des cauchemars et chez ceux qui souffrent de troubles de la personnalité. L'incidence des réactions suffisamment graves pour nécessiter une intervention pharmacologique (benzodiazépines iv) sera inférieure à $1 \%$ des cas si la sélection des patients est judicieuse et si la récupération se déroule dans une secteur paisible. Dans les SDU où cet environnement est inaccessible, la sédation à la kétamine est difficilement réalisable. La plupart des SDU restreint la sédation à la kétamine aux enfants dont l'âge est inférieur à 10 ans ; on y administre avec la kétamine une perite dose prophylactique de benzodiazépine (par exemple, midazolam $0,1 \mathrm{mg} \cdot \mathrm{kg}^{-1} \mathrm{po}$ ).

Avec la kétamine, on doit s'attendre à des augmentations de la pression intracrânienne, de la pression artérielle et de la fréquence cardiaque qui limitent son utilisation chez certains patients. Les patients souffrant d'une IVRS ou d'une infection pulmonaire, fréquents en urgence pédiatrique, sont sujets au laryngospasme si on intervient sur les voies aériennes supérieures sous sédation à la kétamine. La salivation est abondante et peut prédisposer au spasme laryngé. La disponibilité immédiate du matériel nécessaire à la respiration artificielle est obligatoire là où on administre de la kétamine pour la sédation pédiatrique.

La dose requise pour la sédation dissociative est de 4 $\mathrm{mg} \cdot \mathrm{kg}^{-1} \mathrm{po}$, de $2 \mathrm{mg} \cdot \mathrm{kg}^{-1} \mathrm{im}$, et de 0,2 à $0,5 \mathrm{mg} \cdot \mathrm{kg}^{-1}$ iv et doit être titrée jusqu'à l'effet désiré. Ces voies d'administration sont particulièrement utiles chez les enfants pour des interventions de 45 à 60 minutes et la période de récupération est à peu près la même, soit de 1 à 4 heures. La préparation intraveineuse qui a un goût amer est administrée ordinairement po dans un mélange avec un liquide comme l'élixir d'acétaminophène ou un jus de fruit. Le monitorage est le même que celui qu'on utilise pour la sédation profonde. Une attention spéciale doit être accordée aux recommandations concernant le congé à cause de la durée prolongée de l'instabilité motrice qui persiste après la sédation à la kétamine et le risque de chute et de blessure qu'elle entraîne.

\section{La pacification rapide}

Aucune discussion sur la sédation à l'urgence ne serait complète sans la mention des méthodes de pacification rapide chez le patient combatif. ${ }^{28-30} \mathrm{Le}$ patient typique est un traumatisé du crâne qui présente différents degrés d'intoxication, d'insuffisance ventilatoire et d'instabilité hémodynamique. Bien que différents sédatifs puissent être utilisés dans cette situation, aucun ne procure le même degré de stabilité cardiopulmonaire que les butyrophénones, l'halopéridol (Haldol) et la dropéridol (Inapsine).

Parce qu'ils causent peu de dépression respiratoire et ont de légères propriétés alpha bloquantes(dropéridol > halopéridol), ces agents sont idéaux dans cette situation. La dose usuelle des deux agents commence à 0,1 $\mathrm{mg} \cdot \mathrm{kg}^{-1} i v$ en bolus et à répéter toutes les 5 à $10 \mathrm{mi}-$ nutes jusqu'à un maximum total de $0,5 \mathrm{mg} \cdot \mathrm{kg}^{-1}$. Alors que des doses beaucoup plus élevées (jusqu'à $550 \mathrm{mg}$ d'halopéridol) ont été utilisées avec le maintien d'une stabilité cardiopulmonaire remarquable, l'auteur préfêre ajouter une benzodiazépine à petites doses pour arriver à l'effet désiré. La réduction de la dose est alors plus importante que si chacun des médicaments était utilisé seul. Si un accès veineux est impossible à obtenir chez un patient à cause de sa combativité, le dropéridol im (même dose que $i v$ ) peut atteindre son effet aussi rapidement que l'halopéridol $i v .{ }^{31}$ 
TABLEAU III Produits utilisés pour la sédation au SDU avec leurs doses

\begin{tabular}{|c|c|c|c|}
\hline Produit & Sédation Légère & Sédation Profonde & Induction \\
\hline Midazolam & $\begin{array}{l}\text { po } 0,5 \mathrm{mg} \cdot \mathrm{kg}^{-1} \\
\text { max. } 10 \mathrm{mg} \\
\text { MR } 0,25 \mathrm{mg} \cdot \mathrm{kg}^{-1} \times 1 \\
\max \text {. Total } 15 \mathrm{mg} \\
\text { im } 0,1 \mathrm{mg} \cdot \mathrm{kg}^{-1}\end{array}$ & $\begin{array}{l}0,01-0,1 \mathrm{mg} \cdot \mathrm{kg}^{-1} \\
\text { titrage sclon l'effet } \\
\text { Pas de maximum }\end{array}$ & $0,1-0,35 \mathrm{mg} \cdot \mathrm{kg}^{-1}$ \\
\hline Thiopentone & N/A & $\begin{array}{l}0,2 \mathrm{mg} \cdot \mathrm{kg}^{-1} \text { titrage selon } \\
\text { l'effet } i v \\
\text { pas de maximum }\end{array}$ & $3-5 \mathrm{mg} \cdot \mathrm{kg}^{-1}$ \\
\hline Méthohexitone & $\mathrm{N} / \mathrm{A}$ & $\begin{array}{l}0,1 \mathrm{mg} \cdot \mathrm{kg}^{-1} \text { titrage selon } \\
\text { l'effet ip } \\
\text { pas de maximum }\end{array}$ & $\begin{array}{l}1-2 \mathrm{mg} \cdot \mathrm{kg}^{-1} \\
1-2 \mathrm{mg} \cdot \mathrm{kg}^{-1}\end{array}$ \\
\hline Propofol & $\mathrm{N} / \mathrm{A}$ & $\begin{array}{l}0,1 \mathrm{mg} \cdot \mathrm{kg}^{-1} \text { titrage selon } \\
\text { l'effet iv } \\
\text { pas de maximum }\end{array}$ & \\
\hline Etomidate & $\mathrm{N} / \mathrm{A}$ & $\mathrm{N} / \mathrm{A}$ & $0,3 \mathrm{mg} \cdot \mathrm{kg}^{-1}$ \\
\hline Hydrate de chloral & po $50 \mathrm{mg} \cdot \mathrm{kg}^{-1}$ & $\begin{array}{l}\text { po } 70-80 \mathrm{mg} \cdot \mathrm{kg}^{-1} \\
\text { maximum } 2 \mathrm{~g}\end{array}$ & $N / A$ \\
\hline Pentobarbital & im $2 \mathrm{mg} \cdot \mathrm{kg}^{-1}$ & im jusqu'à $6 \mathrm{mg} \cdot \mathrm{kg}^{-1}$ & $N / A$ \\
\hline Kétamine & $\mathrm{N} / \mathrm{A}$ & $\begin{array}{l}\text { iv } 0,1-0,5 \mathrm{mg} \cdot \mathrm{kg}^{-1} \\
\text { im } 1-2 \mathrm{mg} \cdot \mathrm{kg}^{-1} \\
\text { po } 4 \mathrm{mg} \cdot \mathrm{kg}^{-1}\end{array}$ & $1-15 \mathrm{mg} \cdot \mathrm{kg}^{-1}$ \\
\hline
\end{tabular}

Les morphiniques puissants

En introduisant de nouveaux morphiniques synthétiques comme le fentanyl, le sufentanil et l'alfentanil, on visait l'abolition complète les réponses sympathicoadrénergiques pendant l'anesthésie cardiaque. La popularité du fentanyl et de l'alfentanil chez les urgentologues provient de ce que leur début d'action est rapide, leur durée d'action limitée et qu'ils ont peu d'effets cardiovasculaires secondaires. ${ }^{32,33}$ Alors que le fentanyl possède la même demi-vie d'élimination terminale que la mépéridine et la morphine (130-220 $\mathrm{min}$ ), sa haute solubilité dans les graisses lui confère une activité clinique éphémère (30 min). Le mauvais côté de cette solubilité lipidique est une tendance à l'accumulation et la prolongation des effets cliniques avec les doses élevées. L'alfentanyl, d'autre part, a une demi-vie d'élimination terminale de 80 minutes ce qui réduit la tendance à l'accumulation. Les deux agents dépriment la respiration profondément mais ont très peu d'effets cardio-vasculaires chez les patients hémodynamiquement stables. Administrés rapidement et à doses élevées, ces agents provoquent une rigidité musculaire inquiétante pour la respiration.

Les doses usuelles utilisées à l'urgence varient de 1 à $3 \mu \mathrm{g} \cdot \mathrm{kg}^{-1}$ pour le fentanyl ou de 8 à $10 \mu \mathrm{g} \cdot \mathrm{kg}^{-1}$ pour l'alfentanil. Avec des durées d'action de 20 à 30 minutes, ces agents sont très efficaces contre les épisodes
TABLEAU IV Caractéristiques des morphiniques utiles à l'urgence.

\begin{tabular}{lllll}
\hline Produit & $\begin{array}{l}\text { Puissance } \\
\text { Relative }\end{array}$ & $\begin{array}{l}\text { Demi-vie } \\
\text { (min) }\end{array}$ & $\begin{array}{l}\text { Dose } \\
\text { Usuelle } \\
(\text { mg ou } \text { ug }\end{array}$ & $\begin{array}{l}\text { Corg-1 } \\
\text { Can\$ } \$\end{array}$ \\
\hline Morphine & 1 & 130 & $0,15-0,2$ & 0,19 \\
Démérol & 0,20 & 210 & $1-2$ & 0,18 \\
Fentanyl & 120 & 220 & $1-2$ & 1,39 \\
Alfentanil & 30 & 80 & $5-7$ & 1,50 \\
\hline
\end{tabular}

douloureux de 20 à 30 minutes mais mal adaptés à la gestion à plus long terme de la douleur forte pour laquelle la mépéridine ou la morphine sont plus appropriées.

Le développement de lignes de conduite : la sédation profonde à l'urgence

L'élaboration d'une politique écrite sur la sédation profonde au SDU constitue le cadre tout désigné pour rapprocher l'anesthésiste de l'urgentologue. Il leur faudra élaborer conjointement des énoncés de principe sur les questions suivantes :

1. Qui doit agir et qui doit s'abstenir ? (par exemple l'urgentologue, l'orthopédiste, etc.)

2. Qui est responsable et de quoi ? (par exemple, de l'administration des médicaments, de la documentation, etc.) 
3. Dans quel secteur du SDU effectuer la sédation.

4. Quelles mesures de sécurité maintenir sur place (par exemple, oxygène, moniteurs)

5. Le rôle du personnel de soutien

6. Les politiques de répartition des médicaments

7. La documentation

8. Les modalités de la consultation et de l'appel à l'anesthésiste de garde.

Dans ce processus, les participants doivent porter leur attention sur la qualité des soins et l'efficacité du SDU. Il est important de reconnaître que des spécialistes comme les orthopédistes, les plasticiens, les gastroentérologues et autres désireront pratiquer la sédation profonde à l'urgence, ce qui est à considérer dans l'énoncé de principe.

Ordinairement, le processus de sédation profonde au SDU exige en plus d'un médecin qualifié, la présence d'une infirmière formée en soins d'urgence pour aider à la surveillance et à la documentation pendant l'intervention.

\section{Problèmes spéciaux}

Dans l'opinion de l'auteur, l'American Academy of Pediatrics (AAP) a fait un excellent travail en ce qui concerne les problèmes du congé, de l'estomac plein et du monitorage chez les patients soumis à une sédation profonde dont voici le résumé.

Critères de congé (avec un accompagnant fiable)

1. La fonction cardio-vasculaire et l'intégrité des voies aériennes est satisfaisante et stable.

2. Le patient peut être éveillé facilement et les réflexes protecteurs de ses voies aériennes sont intacts.

3. Le patient peut parler (en tenant compte de l'âge).

4. Le patient peut s'asseoir sans aide (en tenant compte de l'âge).

5. Chez le patient très jeune ou le handicapé habituellement incapable de s'exprimer, le niveau de réactivité existant avant la sédation ou un niveau aussi près que possible du niveau normal pour cet individu devrait être réapparu.

6. L'état d'hydratation est adéquat (c.-à-d. qu'il tolère les liquides par la bouche).

Les patients libérés seuls après une sédation profonde ou dissociative doivent être complètement capables de prendre soin d'eux-mêmes et de se protéger.

L'estomac plein

Si on ne peut être assuré du jeûne, les risques de la sédation doivent être mis en balance avec ses avantages et la sédation efficace la plus légère que possible doit être utilisée. En termes pratiques, ceci peut signifier qu'un patient normalement opéré sous sédation profonde à l'urgence sera dirigé vers la salle d'opération sous les soins de l'anesthésie.

\section{Monitorage}

La sédation profonde et l'anesthésie générale sont inséparables en autant que le monitorage est concerné.

\section{Conclusion}

Comme en radiologie, en endoscopie et dans plusieurs secteurs spécialisés des hôpitaux modernes, des patients sont mis sous sédation quotidiennement à l'urgence. Les situations sont entièrement identiques excepté pour le fait que les départements d'urgence sont équipés pour réanimer les patients et que les médecins qui travaillent dans ces départements possèdent une habilité modérée à avancée pour la prise en charge des voies aériennes.

Il appartient aux anesthésistes et aux urgentologues de coopérer pour assurer un standard de soins adéquats aux patients sous sédation et sous analgésie au SDU et dans d'autres secteurs de l'hôpital. Comme pour toute spécialité dont le rôle est étendu, la médecine d'urgence doit avoir recours à la compétence de plusieurs autres disciplines plus spécialisées sur une base quotidienne. L'anesthésie est capable de contribuer avec ses ressources éducationnelles, expérimentales et pratiques l'administration de la sédation et de l'analgésie à l'urgence.

\section{Références}

(Voir page R58) 